\title{
ANALISIS SEKTOR PRIMER UNGGULAN KABUPATEN SRAGEN DAN DISTRIBUSI SPASIALNYA TAHUN 2016-2017
}

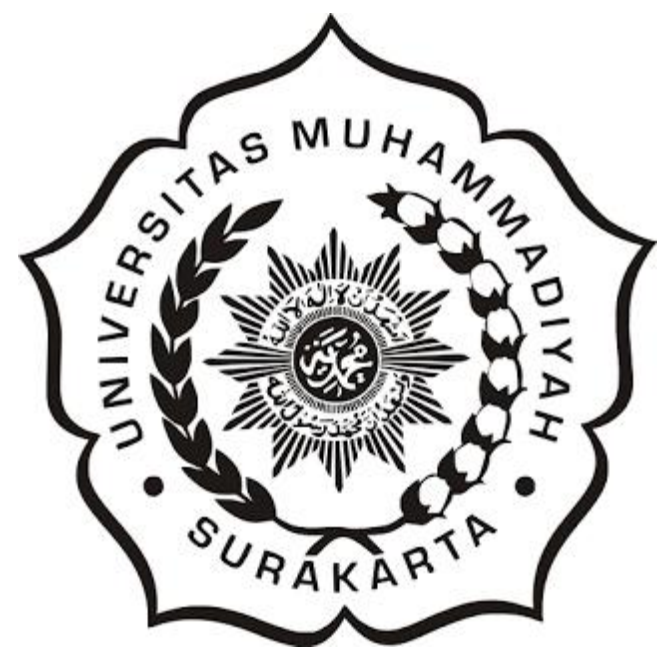

\section{Skripsi}

Diajukan Untuk Memenuhi Tugas dan Syarat-syarat Guna Memperoleh Gelar Sarjana Ekonomi Jurusan Ekonomi Pembangunan Fakultas Ekonomi dan Bisnis Universitas Muhammadiyah Surakarta

Disusun Oleh:

YESSY SEPTYANI

B300160025

PROGRAM STUDI EKONOMI PEMBANGUNAN

FAKULTAS EKONOMI DAN BISNIS

UNIVERSITAS MUHAMMADIYAH SURAKARTA 


\title{
ANALISIS SEKTOR PRIMER UNGGULAN KABUPATEN SRAGEN DAN DISTRIBUSI SPASIALNYA TAHUN 2016-2017
}

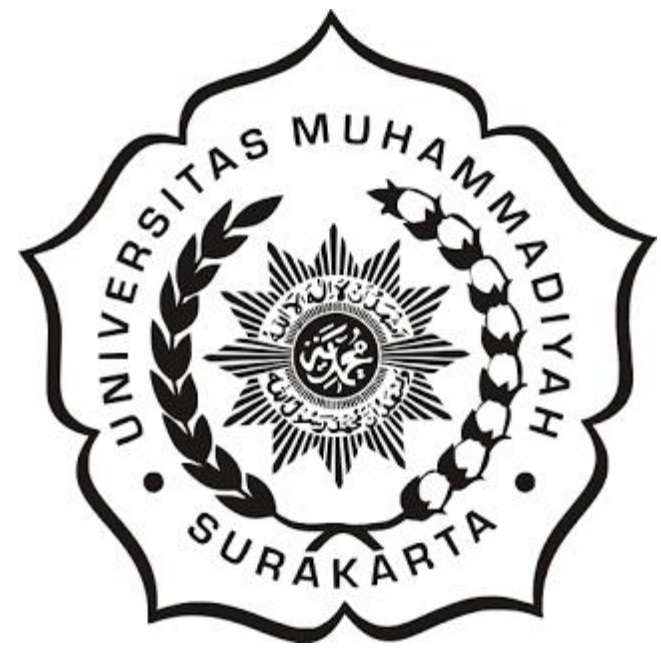

\section{Skripsi}

Diajukan Untuk Memenuhi Tugas dan Syarat-syarat Guna Memperoleh Gelar Sarjana Ekonomi Jurusan Ekonomi Pembangunan Fakultas Ekonomi dan Bisnis Universitas Muhammadiyah Surakarta

Disusun Oleh:

\section{YESSY SEPTYANI}

B300160025

\author{
PROGRAM STUDI EKONOMI PEMBANGUNAN \\ FAKULTAS EKONOMI DAN BISNIS \\ UNIVERSITAS MUHAMMADIYAH SURAKARTA
}




\title{
HALAMAN PERSETUJUAN
}

\section{ANALISIS SEKTOR UNGGULAN PRIMER KABUPATEN SRAGEN DAN DISTRIBUSI SPASIALNYA TAHUN 2016-2017}

\author{
SKRIPSI \\ Oleh:

\section{YESSY SEPTYANI}

B300160025

Telah diperiksa dan disetujui untuk diuji oleh :

Suakarta, 27 Juli 2019

Pembimbing

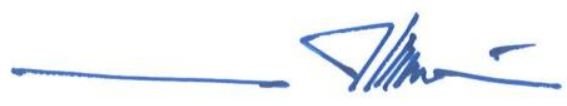

(Muhammad Arif, SE. MEc. Dev) 
HALAMAN PENGESAHAN

ANALISIS SEKTOR PRIMER UNGGULAN KABUPATEN SRAGEN DAN DISTRIBUSI SPASIALNYA TAHUN 2016-2017

Oleh :

\section{YESSY SEPTYANI}

B300160025

Telah dipertahankan di depan dewan penguji

Fakultas Ekonomi dan Bisnis

Universitas Muhammadiyah Surakarta

Pada Hari

Dan dinyatakan telah memenuhi syarat

\section{Dewan Penguji:}

1. Muhammad Arif, SE. MEc. Dev

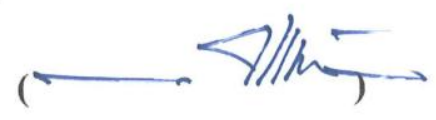

(Ketua Dewan Penguji)

2. Dr Daryono Soebagiyo, MEC

(Anggota I Dewan Penguji)

3. Eni Setyowati, SE.Msi

(Anggota II Dewan Penguji)

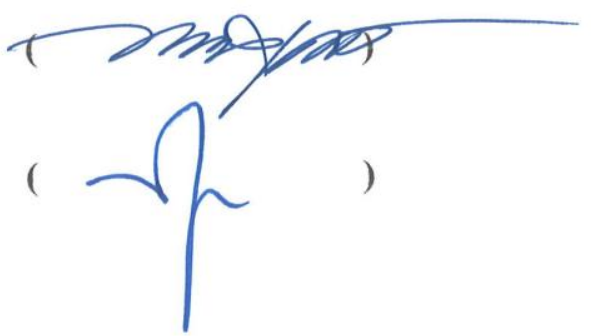

Dekan Fakultas Ekonomi dan Bisnis

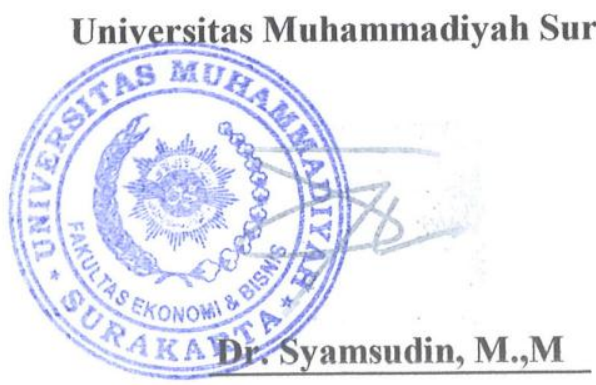




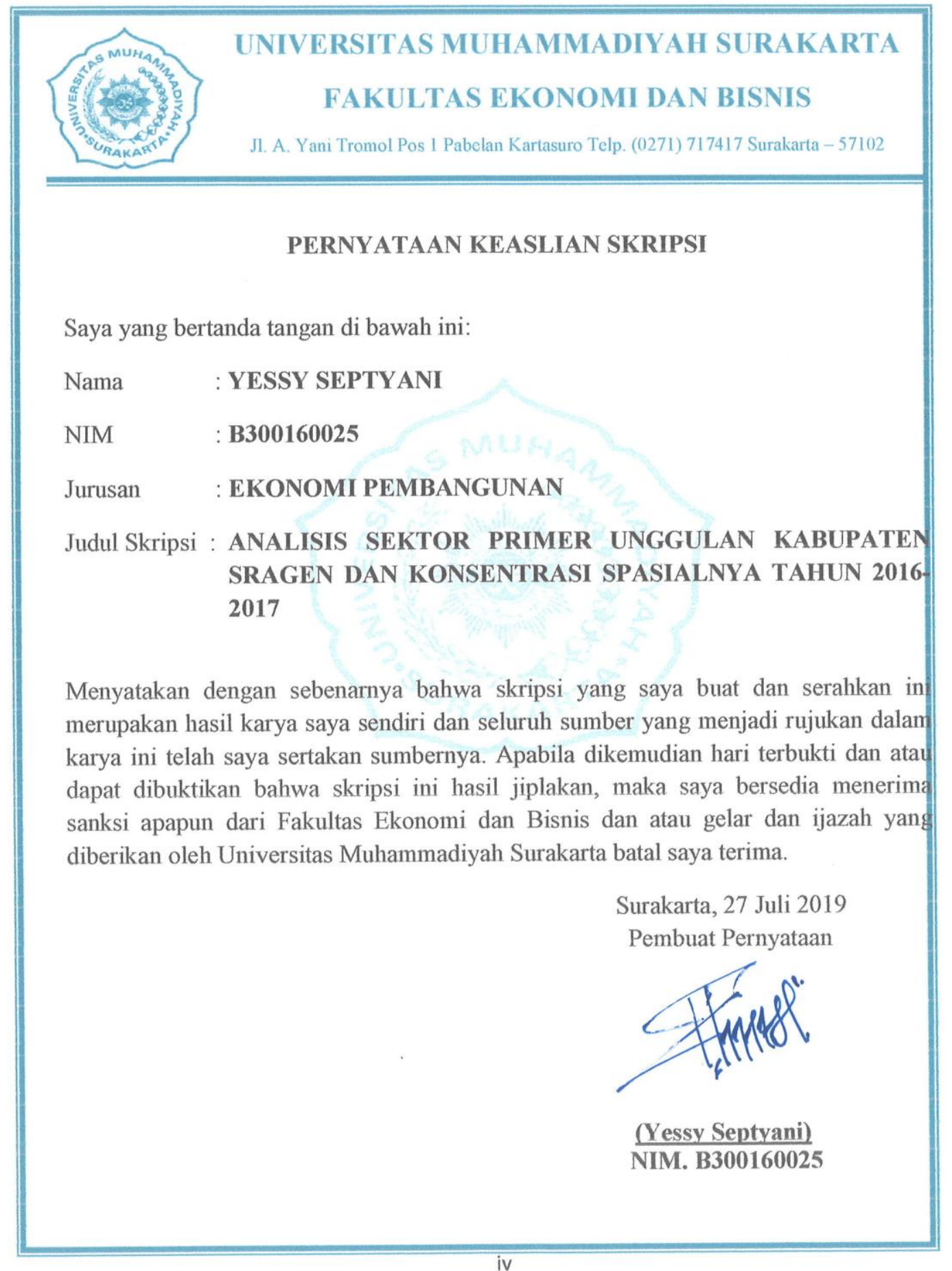




\section{MOTTO}

“Tidak ada kesuksesan melainkan dengan pertolongan Allah”

(Q.S. Huud:88)

"Sukses adalah saat persiapan dan kesempatan bertemu”

(Bobby Unser)

"Mulailah dari tempatmu berada. Gunakan yang kau punya. Lakukan yang kau bisa”

(Arthur Ashe)

"Hidup ini seperti sepeda. Agar tetap seimbang, kau harus terus bergerak"

(Albert Einstein) 


\section{PERSEMBAHAN}

Dengan mengucap syukur Alhamdulillah kepada Allah SWT atas rahmat dan karunia-Nya hingga terselesaikan skripsi ini, penulis persembahkan untuk:

1. Allah SWT yang telah memberi anugrah di dalam hidupku dan senantiasa mencurahkan nikmat yang luar biasa setiap waktu.

2. Rasulullah SAW semoga shalawat dan salam selalu tercurah kepada Beliau Baginda Nabi Muhammad SAW, keluarga serta sahabat

3. Kedua Orang Tuaku, Ibu (Sukiyem) dan Bapak (Guno Wiyono) tercinta yang penuh kesabaran dan cinta kasih sayang yang telah mengasuh serta mendidik saya sejak kecil, dan selalu memberikan dukungan dan doa dalam setiap langkahku.

4. Saudara-saudaraku tercinta yang selalu memberikan dukungan dan do'a.

5. Sahabat-sahabatku tercinta April, Meilis, Erika, Emi, Vivi dan mbak Pita. Terima kasih atas segala dukungan, motivasi, do'a, canda tawa dan bantuan macammacam selama ini.

6. Sahabat-sahabat SMA ku Avisah, Ratih dan Dian. Terima kasih atas semua dukungan, do’a, motivasi, perhatian serta pengertiannya selama ini.

7. Kepada orang teristimewa, dan tersayang (Ridwan Ibnu Prayogo) yang selalu memberikam dukungan, motivasi, semangat dan doa selama ini.

8. Teman-teman seperjuanganku di FEB UMS

9. Almamater Universitas Muhammadiyah Surakarta.

10. Semua pihak yang tidak dapat saya sampaikan satu persatu. 


\section{KATA PENGANTAR}

Puji Syukur Alhamdulillah penulis panjatkan kehadirat Allah SWT yang telah melimpahkan rahmat dan karunia-Nya berupa ilmu pengetahuan, kesehatan dan petunjuk, sehingga penulis dapat melaksanakan penelitian dan menyelesaikan penulisan skripsi dengan judul "Analisis Sektor Primer Unggulan Kabupaten Sragen Dan Distribusi Spasialnya Tahun 2016-2017", sebagai salah satu persyaratan dalam memperoleh gelar Sarjana Ekonomi di Fakultas Ekonomi Dan Bisnis Universitas Muhammadiyah Surakarta. Sholawat dan salam tak lupa penulis haturkan kepada Rasulullah SAW. Yang telah menjadi suri tauladan yang baik yang mengajarkan kebenaran dan kebaikan.

Pelaksanaan penelitian serta proses penyelesaian skripsi ini dapat terlaksana dengan lancar berkat do'a dan dukungan dari berbagai pihak. Oleh karena itu, penulis mengucapkan terima kasih sebesar-besarnya kepada:

1. Kedua orang tua tercinta, Ibu Sukiyem dan Bapak Guno Wiyono yang selalu memberikan do'a, motivasi, dan dorongan demi terselesainya skripsi ini.

2. Bapak Dr. Sofyan Arif, M.Si selaku Rektor Universitas Muhammadiyah Surakarta

3. Bapak Dr. Syamsudin, MM selaku Dekan Fakultas Ekonomi dan Bisnis Universitas Muhammadiyah Surakarta. 
4. Ibu Ir. Maulidyah Indira Hasmarini, MS selaku Ketua Program Studi Ekonomi Pembangunan Fakultas Ekonomi dan Bisnis Universitas Muhammadiyah Surakarta.

5. Bapak Dr. Daryono Soebagiyo selaku Sekprodi I Program Studi Ekonomi Pembangunan Fakultas Ekonomi dan Bisnis Universitas Muhammadiyah Surakarta.

6. Ibu Eni Setyowati, SE. M.Si selaku Sekprodi II Program Studi Ekonomi Pembangunan Fakultas Ekonomi dan Bisnis Universitas Muhammadiyah Surakarta.

7. Bapak Muhammad Arif, SE. Mec. Dev selaku dosen pembimbing skripsi yang telah memberikan waktu, tenaga dan pikiran serta kesabaran dalam membimbing dan mengarahkan penulis dalam menulis skripsi.

8. Bapak/Ibu Dosen Program Studi Ekonomi Pembangunan Fakultas Ekonomi dan Bisnis Universitas Muhammadiyah Surakarta yang telah memberikan ilmu kepada penulis.

9. Seluruh pegawai, Staf Akademik, Staf jurusan Ilmu Ekonomi Pembangunan Universitas Muhammadiyah Surakarta yang memberikan bantuan dalam penulisan skripsi ini.

10. Pimpinan dan Karyawan Perpustakaan Universitas Muhammadiyah Surakarta yang telah memberikan informasi, data, referensi lain-lain

11. Teman-teman dan sahabat yang tidak dapat saya sebutkan satu persatu yang selalu memberi semangat dan dukungan dalam mengerjakan skripsi. 
12. Teman-teman almamater IESP FEB UMS yang memberi semangat dan dukungan.

Semoga segala bantuan yang sudah diberikan kepada penulis kelak dibalas oleh Allah SWT, penulis menyadari bahwa skripsi ini jauh dari kesempurnaan, akan tetapi diharapkan dapat memberikan manfaat keilmuwan yang berarti bagi khalayak umum.

Surakarta, 27 Juli 2019

Penulis

Yessy Septyani 


\section{DAFTAR ISI}

HALAMAN JUDUL .............................................................................. $\mathrm{i}$

HALAMAN PERSETUJUAN ................................................................ ii

HALAMAN PENGESAHAN ................................................................ iii

PENYATAAN KEASLIAN SKRIPSI ..................................................... iv

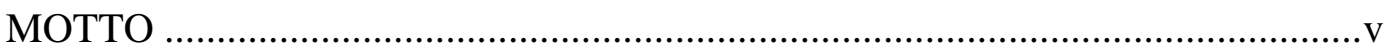

PERSEMBAHAN ............................................................................. vi

KATA PENGANTAR ..................................................................... vii

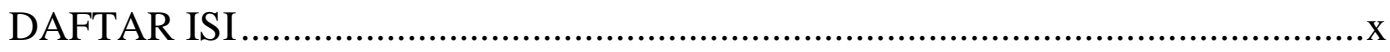

DAFTAR TABEL ................................................................................ xiii

DAFTAR GAMBAR ....................................................................... xiv

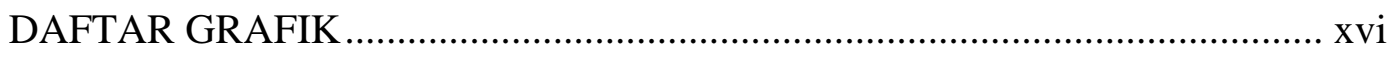

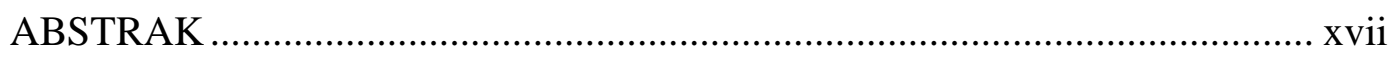

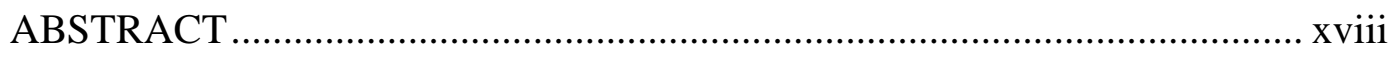

BAB I PENDAHULUAN ......................................................................... 1

A. Latar Belakang .......................................................................

B. Rumusan Masalah ....................................................................

C. Tujuan Penelitian .....................................................................

D. Manfaat Penelitian ............................................................................ 5

E. Metode Penelitian.......................................................................... 5

1. Jenis dan Sumber Data ..........................................................

2. Alat dan Model Analisis.........................................................6 
F. Sistematika Penulisan ..................................................................

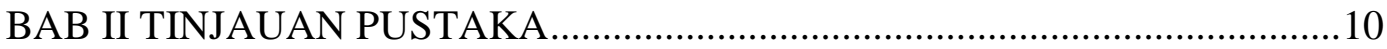

A. Konsep Pertumbuhan dan Pembangunan Ekonomi ...............................10

B. Teori Pertumbuhan Ekonomi Wilayah.................................................17

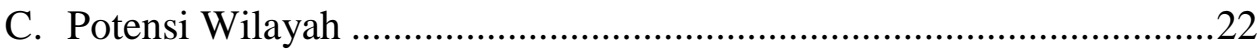

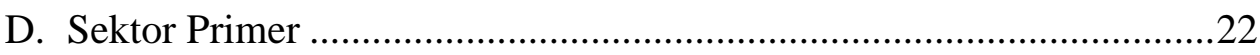

E. Teori Sektor Unggulan .........................................................................30

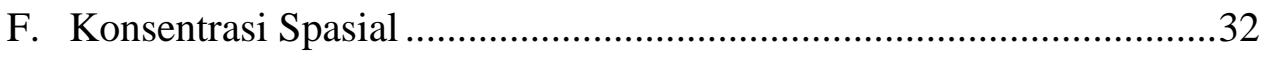

G. Teori Lokasi Weber...............................................................................33

H. Penelitian Terdahulu .........................................................................

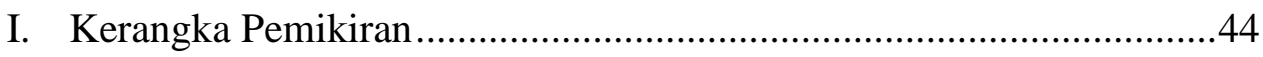

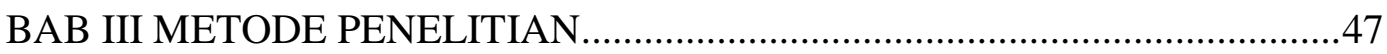

A. Alat dan Model Analisis......................................................................47

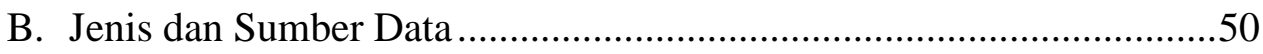

C. Jenis Penelitian dan Lokasi Penelitian ...................................................51

BAB IV HASIL PENELITIAN DAN ANALISIS DATA ………….....................52

A. Kondisi Umum Kabupaten Sragen......................................................52

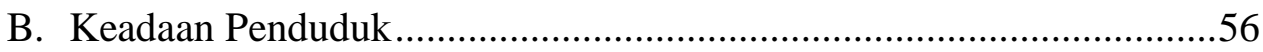

C. Pembahasan Dan Hasil Penelitian ........................................................59

1. Pembahasan ...............................................................................

a. Analisis Komoditas Sektor Pertanian ....................................59 
b. Keadaan Sektor Pertanian ..................................................60

2. Hasil Analisis ......................................................................66

a. Analisis Dyanmic Location Quotient (DLQ) ........................66

b. Analisis Sistem Informasi Geografis (SIG) ..........................75

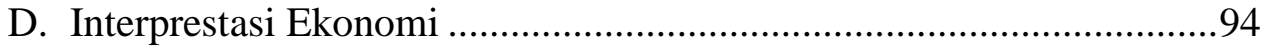

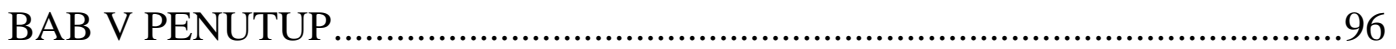

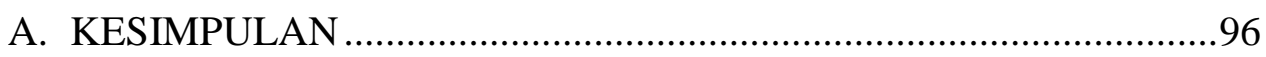

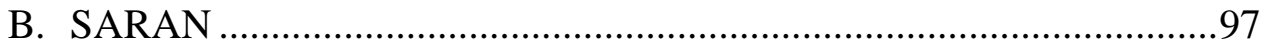

DAFTAR PUSTAKA

LAMPIRAN 


\section{DAFTAR TABEL}

Tabel 4.1 Luas Wilayah Kabupaten Sragen tahun 2018 …………………….....53

Tabel 4.2 Jenis Penggunaan Lahan (ha) Menurut Kecamatan di Kabupaten Sragen

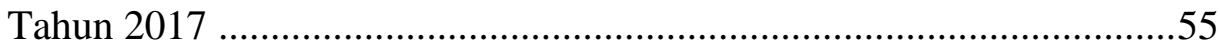

Tabel 4.3 Jumlah Penduduk Kabupaten Sragen Tahun 2017 ................................57

Tabel 4.4 Jumlah Produksi Sub Sektor Tanaman Pangan Tahun 2016-2017 ........62

Tabel 4.5 Jumlah Produksi Sub Sektor Holtikultura Tahun 2016-2017 ................63

Tabel 4.6 Jumlah Produksi Sub Sektor Biofarmaka Tahun 2016-2017 ..................64

Tabel 4.7 Jumlah Produksi Sub Sektor Perkebunan Tahun 2016-2017 ..................65

Tabel 4.8 Jumlah Produksi Sub Sektor Perikanan Tahun 2016-2017.....................65 


\section{DAFTAR GAMBAR}

Gambar 2.1 Kurva Kemungkinan Produksi ................................................... 16

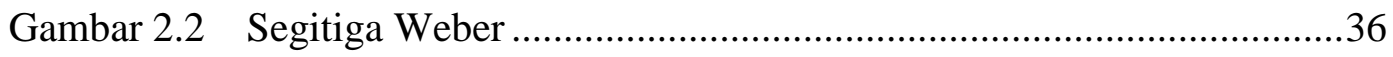

Gambar 2.3 Kerangka Pemikiran ..................................................................46

Gambar 4.1 Peta Administratif Kabupaten Sragen ........................................52

Gambar 4.2 Peta Kepadatan Penduduk Kabupaten Sragen ..............................58

Gambar 4.3 Gambar Penangkapan Ikan di Waduk Kedung Ombo ....................74

Gambar 4.4 Peta Sebaran Wilayah Penghasil Komoditas Kacang Hijau ...........76

Gambar 4.5 Produk Susu Kaleyo UMKM Brayat Manunggal ..........................78

Gambar 4.6 Produk Susu Kaleyo Kemasan Sachet UMKM Brayat Manunggal78

Gambar 4.7 Peta Sebaran Wilayah Penghasil Komoditas Cabe besar di Kabupaten

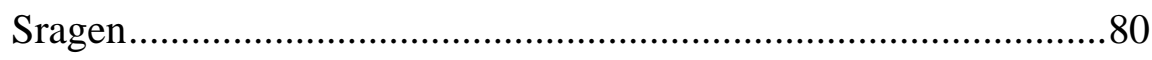

Gambar 4.8 Potret Penjualan Cabe Besar di Pasar Bunder Sragen.....................82

Gambar 4.9 Peta Sebaran Wilayah Penghasil Komoditas Tomat di Kabupaten

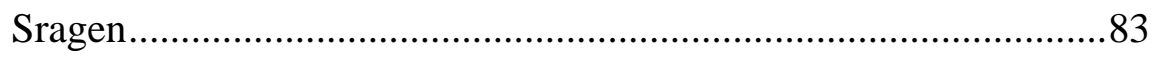

Gambar 4.10 Peta Sebaran Wilayah Penghasil Komoditas Kangkung di Kabupaten

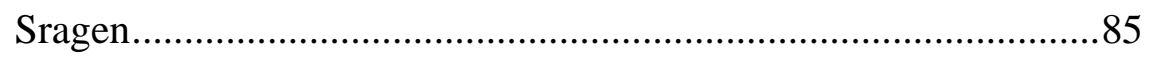

Gambar 4.11 Peta Sebaran Wilayah Penghasil Komoditas Terong di Kabupaten Sragen. . .87

Gambar 4.12 Peta Sebaran Wilayah Penghasil Komoditas Semangka di Kabupaten

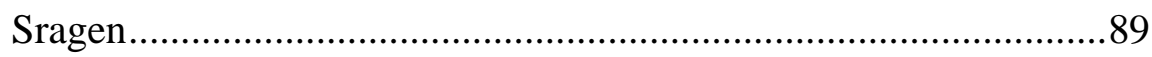


Gambar 4.13 Peta Sebaran Wilayah Penghasil Komoditas Pisang di Kabupaten

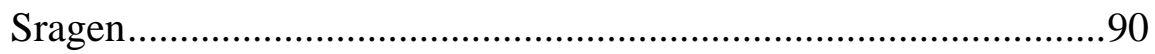

Gambar 4.14 Produk UMKM Keripik Pisang di Kabupaten Sragen .....................94 


\section{DAFTAR GRAFIK}

Grafik 4.1 Komposisi Produk Domestik Regional Bruto Kabupaten Sragen 2017

Grafik 4.2 Nilai Komoditas Sub Sektor Tanaman Pangan di Kabupaten Sragen berdasarkan nilai DLQ Tahun 2016-2017 67

Grafik 4.3 Nilai Komoditas Sub Sektor Holtikultura di Kabupaten Sragen berdasarkan nilai DLQ Tahun 2016-2017

Grafik 4.4 Nilai Komoditas Sub Sektor Biofarmaka di Kabupaten Sragen berdasarkan nilai DLQ Tahun 2016-2017 70

Grafik 4.5 Nilai Komoditas Sub Sektor Perkebunan di Kabupaten berdasarkan nilai DLQ Tahun 2016-2017 72

Grafik 4.6 Nilai Komoditas Sub Sektor Perikanan di Kabupaten berdasarkan nilai DLQ Tahun 2016-2017 . .73 


\begin{abstract}
ABSTRAK
Tujuan pembangunan daerah adalah untuk meningkatkan taraf hidup dan kesejahteraan masyarakat. Oleh sebab tersebut, pemerintah daerah harus berupaya untuk dapat meningkatkan kesejahteraan masyaraktnya. Peningkatan kesejahteraan masyarakat dapat bisa dilakukan melalui pengembangan potensi yang ada melalui komoditas unggulan.

Tujuan dari penelitian ini adalah untuk mengetahui Analisis Sektor Primer Unggulan Kabupaten Sragen dan Distribusi Spasialnya Tahun 2016-2017. Metode Yang digunakan dalam penelitian ini adalah dengan menggunakan analisis Dynamic Location Quotient (DLQ) dan Sistem Informasi Geografis (SIG). Data yang digunakan berupa data produksi komoditas primer Kabupaten Sragen tahun 20162017 dan data produksi komoditas primer Provinsi Jawa Tengah tahun 2016-2017.

Dari hasil analisis dapat disimpulkan bahwa dari hasil analisis $D L Q$ menunjukkan sektor primer yang menjadi komoditas unggulan adalah kacang hijau, cabe besar, tomat, kangkung, terong, semangka, pisang dan perikanan budidaya. Sedangkan berdasarkan model pendekatan Sistem Informasi Geografis (SIG) menunjukkan bahwa komoditas primer unggulan kacang hijau tersebar di wilayah Tanon. Cabe besar tersebar di wilayah Kedawung, Tanon, Plupuh, Gemolong, Gondang, Kalijambe, Karangmalang, Masaran, Miri, Ngrampal, Sambungmacan, Sambirejo, Sumberlawang dan Sukodono. Tomat tersebar di wilayah Gemolong, Sidoharjo dan Tanon. Kangkung tersebar di wilayah Miri, Mondokan, Sukodono. Terong tersebar di wilayah Kecamatan Mondokan, Sambungmacan dan Tangen. Semangka tersebar di wilayah Plupuh dan Sumberlawang. Pisang tersebar di wilayah Gemolong, Gesi, Gondang, Jenar, Kalijambe, Kedawung, Masaran, Miri, Mondokan, Ngrampal, Plupuh, Sambirejo, Sambungmacan, Sukodono, Sumberlawang, Tangen dan Tanon.
\end{abstract}

Kata Kunci : Sektor Unggulan, Dynamic Location Quotient (DLQ), Sistem Informasi Geografis (SIG). 


\begin{abstract}
ABSTRACK
The purpose of regional development is to improve the standard of living and welfare of the community. Therefore, local governments must strive to improve the welfare of the community. Improving community welfare can be done through developing existing potential through superior commodities.

The purpose of this study was to find out the analysis of the superior primary out the superior primary sector of Sragen District and its spatial distribution in 20162017. The method used in this study is to use Dynamic Location Quotient (DLQ) and Geographic Information System (SIG). The data used in the form of Sragen Regency primary commodity production data in 2016-2017 and primary commodity production data for Central Java ProvinceS 2016-2017.

From the result if the analysis, it can be concluded that from the result of $D L Q$, the primary sector which is the leading commodity is green beans, large chillies, tomatoes, kale, eggplant, watermelon, bananas and aquaculture. Wheareas based on thr geographich information system approach model shows that superior primary commodity of green beans is spread in the Tanon Region. Chili spread in the Kedawung area, Tanon, Plupuh, Gemolong, Gondang, Kalijambe, Karangmalang, Masaran, Miri, Ngrampal, Sambungmacan, Sambirejo, Sumberlawang and Sukodono. Tomatoes spread in the Gemolong area, Sidoharjo and Tanon. Kale spread in the Miri area, Mondokan, Sukodono. Eggplant spread in the Mondokan area, Sambungmacan and Tangen. Semangka tersebar di wilayah Plupuh and Sumberlawang. Watermelon spread in the Plupuh dan Sumberlawang area. Bananas spread in the Gemolong, Gesi, Gondang, Jenar, Kalijambe, Kedawung, Masaran, Miri, Mondokan, Ngrampal, Plupuh, Sambirejo, Sambungmacan, Sukodono, Sumberlawang, Tangen and Tanon.
\end{abstract}

Keywords : Leading Sector, Dynamic Location Quotient (DLQ), Geographic Information System. 


\section{BAB I}

\section{PENDAHULUAN}

\section{A. Latar Belakang}

Setelah ditetapkannya Undang-Undang No. 22 Tahun 1999 tentang Pemerintahan Daerah, maka sistem otonomi daerah menggantikan sistem sentralistik. Tarigan (2005) memberikan penjelasan bahwa dengan kondisi yang demikian, maka masing-masing sudah lebih bebas dalam menetapkan sektor/komoditi yang diprioritaskan pengembangannya. Kemampuan pemerintah daerah untuk melihat sektor yang memiliki keunggulan dan kelemahan di wilayahnya menjadi semakin penting. Sektor yang memiliki keunggulan, memiliki prospek yang lebih baik untuk dikembangkan dan diharapkan dapat mendorong sektor-sektor lain untuk berkembang. Potensi wilayah satu dengan wilayah lainnya pasti berbeda-beda. Karena hal ini terkait dengan karakteristik masing-masing wilayah tersebut.

Otonomi daerah yang berkembang saat ini, di satu sisi memberikan kewenangan yang lebih luas bagi pemerintah daerah dalam mengatur dan melaksanakan program-program pembangunan di daerahnya, namun di sisi lain juga menuntut kesiapan daerah dalam mempersiapkan dan melaksanakan berbagai kebijakan yang kini bergeser menjadi tanggung jawab daerah. Pembangunan daerah di era otonomi daerah perlu dilaksanakan secara terpadu, selaras, serasi dan seimbang serta sesuai dengan prioritas dan potensi daerah (Tjiptoherijanto, 1997). Dengan demikian, pemerintah daerah perlu mengetahui sektor-sektor yang mempunyai 
peranan dominan dalam perekonomian daerahnya, sehingga akan lebih memudahkan pemerintah daerah dalam menetapkan sasaran pembangunan dan memajukan daerahnya, sehingga dalam upaya mencapai tujuan pembangunan ekonomi daerah, kebijakan utama yang perlu dilakukan adalah mengusahakan semaksimal mungkin agar prioritas pembangunan daerah sesuai dengan potensi yang dimiliki oleh daerah.

Kegiatan ekonomi yang bervariasi, mendorong setiap daerah Kabupaten atau Kota untuk mengembangkan potensi ekonominya. Arah dan kebijakan pembangunan daerah digunakan untuk memacu pemerataan pembangunan secara menyeluruh dalam rangka meningkatkan kesejahteraan rakyat, menggalakkan prakarsa dan peran aktif masyarakat serta meningkatkan pendayagunaan potensi daerah secara optimal dan terpadu dalam mengisi otonomi daerah yang nyata, dinamis, serasi dan bertanggung jawab serta memperkuat persatuan dan kesatuan bangsa guna mewujudkan pemerataan hasil pembangunan di tanah air. Pemerataan hasil-hasil pembangunan tidak mungkin dapat tercapai dalam waktu singkat tetapi memerlukan waktu, oleh karena itu yang paling penting dilakukan adalah semua upaya harus diarahkan sedemikian rupa sehingga proses-proses dan pelaksanaan pembangunan nasional dan pembangunan daerah khusunya dan pada setiap tahunnya makin mendekati pada tujuan yang diharapkan. Pembangunan daerah haruslah sesuai dengan kondisi potensi serta aspirasi masyarakat yang tumbuh dan berkembang. Apabila pelaksanaan prioritas pembangunan daerah kurang sesuai dengan potensi yang dimiliki oleh masing-masing daerah, maka pemanfaatan sumber daya yang ada akan menjadi 
kurang optimal. Keadaan tersebut dapat mengakibatkan lambatnya proses pertumbuhan ekonomi daerah yang bersangkutan (Arsyad, 2000).

Pertumbuhan ekonomi adalah salah satu tolak ukur yang dapat dipakai untuk meningkatkan adanya pembangunan suatu daerah dari berbagai macam sektor ekonomi yang secara tidak langsung menggambarkan tingkat perubahan ekonomi. Pertumbuhan ekonomi ini dapat dilihat dan diukur dari perkembangan pendapatan daerah Produk Domestik Regioanl Bruto (PDRB) atas dasar harga konstan dari tahun ketahunnya. Suatu masyarakat dipandang mengalami suatu pertumbuhan dalam kemakmuran masyarakat apabila pendapatan perkapita masyarakat tersebut menurut harga atau pendapatan terus menerus bertambah dalam dinamika pembangunan nasional, PDRB suatu daerah tidak selalu mengalami peningkatan karena sering terjadinya fluktuasi ekonomi. Pembangunan yang dilakukan pemerintah daerah bertujuan untuk meningkatkan PDRB daerah yang bersangkutan. PDRB Kabupaten Sragen disumbang oleh salah satu sektor diantaranya adalah sektor primer yaitu sektor pertanian yang meliputi tanaman pangan, holtikultura biofarmaka, perkebunan, dan perikanan. Berdasarkan data PDRB Kabupaten Sragen atas dasar harga berlaku pada tahun 2016 sektor pertanian menyumbang sebesar 16,63\%, sedangkan pada tahun 2017 sektor pertanian menyumbang sebesar 15,74\%. Dengan presentasi seperti itu sektor pertanian belum mendominasi dalam hal penyumbang PDRB Kabupaten Sragen karena masih kalah tinggi dengan sektor industri yang sebesar 35,30 \% pada tahun 2016 dan 36,07 \% pada tahun 2017, sedangkan sektor perdagangan yang mempunyai presentasi sebesar 18,80 \% di tahun 2016 dan 18,61\% di tahun 2017, 
yang artinya sektor pertanian berada di urutan ketiga setelah sektor industri dan sektor perdagangan.

Tantangan yang dihadapi Kabupaten Sragen dalam pelaksanaan strategi pembangunannya sebagaimana tersebut diatas adalah bagaimana meningkatkan potensi wilayah produktivitas dan efisiensi sektor pertanian dalam menghasilkan berbagai komoditi pertanian agar dapat memberikan nilai tambah yang sebesarbesarnya kepada masyarakat dengan mengoptimalkan segala potensi yang dimiliki daerahnya. Peningkatan produktivitas dan efisiensi sektor pertanian di Kabupaten Sragen dapat dilakukan apabila pemerintah daerah mengetahui potensi wilayahnya di tiap Kecamatan di Kabupaten Sragen karena besarnya kontribusi sektor pertanian di tingkat Kabupaten ditentukan oleh besarnya produksi komoditi pertanian di tingkat Kecamatan. Berdasarkan permasalahan diatas maka diadakan penelitian dengan judul “Analisis Sektor Primer Unggulan Kabupaten Sragen dan Distribusi Spasialnya Tahun 2016-2017 “.

\section{B. Rumusan Masalah}

Berdasarkan uraian latar belakang diatas, maka penelitian ini dirumuskan permasalahan yang hendak dibahas sebagai berikut:

1. Apa saja sektor unggulan komoditas primer di Kabupaten Sragen tahun 2016$2017 ?$

2. Bagaimana Konsentrasi Spasial komoditas primer unggulan di Kabupaten Sragen tahun 2016-2017? 


\section{Tujuan Penelitian}

Tujuan Penelitian yang diharapakan dapat dicapai dalam penelitian ini adalah:

1. Untuk mengetahui sektor unggulan komoditas primer di Kabupaten Sragen tahun 2016-2017.

2. Untuk mengetahui Konsentrasi Spasial komoditas primer unggulan di Kabupaten Sragen tahun 2016-2017.

\section{Manfaat Penelitian}

1. Bagi pembaca, sebagai bahan wacana dan kajian untuk menambah wawasan ilmu pengetahuan terutama dalam hal keterkaitan potensi wilayah sektor primer.

2. Bagi pemerintah, seperti dinas pertanian dapat menjadi referensi dalam menentukan kebijakan guna mengembangkan komoditas primer unggulan di Kabupaten Sragen.

3. Hasil penelitian ini diharapkan bisa menjadi bahan kajian ataupun perbandingan pada penelitian sejenis.

\section{E. Metode Penelitian}

1. Jenis dan Sumber Data

Metode pengumpulan data pada penelitian ini menggunakan metode pengumpulan data kuantitatif dengan jenis data yang digunakan dalam penelitian ini adalah data sekunder. Data ini diperoleh dari BPS Jateng, BPS 
Kabupaten Sragen, dan dari lembaga atau instansi yang terkait dalam penelitian ini. Alat analisis yang diguakan dalam penelitian ini adalah Dynamic Location Quotient (DLQ) dan Sistem Informasi Geografis (SIG). SIG ini digunakan untuk mengetahui pola distribusi spasial komoditas primer di Kabupaten Sragen. SIG pada dasarnya adalah suatu tipe sistem informasi yang memfokuskan pada penyajian dan analisis realitas geografis.

2. Alat dan Analisis Data

a. Analisis Dynamic Location Quotient (DLQ).

Untuk menjawab tujuan yang pertama digunakan alat analisis Dynamic Location Quotient (DLQ), Rumus yang digunakan adalah sebagai berikut:

$$
\text { Rumus DLQ }=\left[\frac{(1+g j) /(1+G j)}{(1+g i) /(1+G i)}\right] \mathrm{t}
$$

Dimana:

$\mathrm{DLQ}_{\mathrm{ij}}=$ Indeks potensi sektor $\mathrm{i}$ di daerah $\mathrm{j}$

gj $\quad=$ Laju pertumbuhan sektor i di regional

$\mathrm{Gj} \quad=$ Rata-rata laju pertumbuhan sektor i di regional

gi = Laju pertumbuhan sektor i di nasional

$\mathrm{Gi}=$ Rata-rata laju pertumbuhan sektor i di nasional

$\mathrm{t} \quad=$ Selisih tahun akhir dan tahun awal 
Nilai DLQ yang dihasilkan dapat diartkan sebagai berikut:

1. DLQ $>1$ : potensi perkembagan sub sektor i di daerah Kabupaten lebih cepat dibandingkan di wilayah referensi Provinsi.

2. DLQ $<1$ : Potensi perkembagan sub sektor i di daerah Kabupaten lebih lambat dibandingkan di wilayah referensi provinsi.

3. $\mathrm{DLQ}=1$ : Potensi perkembagan sub sektor sama cepat dibanding daerah Kabupaten lain di wilayah referensi Provinsi.

b. Analisis Spasial Distribusi Wilayah Sektor Primer

Sedangkan untuk menjawab tujuan kedua, menggunakan analisis spasial geografis yang merupakan alat analisis yang sempurna. Dengan analisis spasial geografis dapat diketahui secara detail pola penyebaran komoditas primer unggulan. Dalam penelitian ini analisis spasial akan menggunakan analisis SIG (Sistem Informasi Geografis). SIG merupakan alat analisis yang bermanfaat untuk : (1) mengindentifikasi lokasi komoditas primer unggulan; (2) di daerah mana mereka cenderung mengelompok secara spasial. Untuk menghasilkan hal tersebut langkahlangkah yang harus ditempuh adalah: Pertama, memberikan peringkat untuk seluruh kecamatan di Kabupaten Sragen komoditas primer, peringkat ini adalah sebagai indikator ketidakmerataan lokasi geografis komoditas primer di Kabupaten Sragen. Kedua, menyajikan data komoditas primer dalam bentuk peta untuk menunjukan dimana lokasi daerah primer dan non 
primer, kemudian dibuat suatu kriteria tertentu yaitu; sangat tinggi, tinggi, menengah dan rendah berdasarkan komoditas primer yang dihasilkan oleh Kabupaten Sragen.

\section{F. Sistematika Penulisan}

Sistematika dari penelitian ini adalah :

BAB I PENDAHULUAN

Dalam bab ini berisi tentang latar belakang masalah, rumusan masalah, tujuan penelitian, manfaat penelitian, metodelogi penelitian serta sistematika penulisan.

BAB II

\section{LANDASAN TEORI}

Dalam bab ini berisi tentang teori-teori yang berhubungan dengan potensi wilayah, konsentrasi spasial serta faktor faktor yang mempengaruhi tinjauan dan penelitian terdahulu

BAB III

\section{METODE PENELITIAN}

Dalam bab ini berisikan tentang ruag lingkup penelitian, jenis dan sumber data, definisi variabel dan metode analisis data.

BAB IV

$$
\begin{aligned}
& \text { ANALISIS DATA DAN PEMBAHASAN } \\
& \text { Dalam bab ini berisi penggarapan data dengan Dynamic } \\
& \text { Location Quotient (DLQ) dan pengukuran pemusatan titik } \\
& \text { spasial analisis data (SIG). }
\end{aligned}
$$


BAB V PENUTUP

Dalam bab ini membahas tentang kesimpulan dan sasaran dari penelitian yang dilakukan.

\section{DAFTAR PUSTAKA}

LAMPIRAN 


\section{DAFTAR PUSTAKA}

Adhitama, Rifki. 2012. "Pengembangan Sektor-Sektor Ekonomi di Tiap Kecamatan Di Kabupaten Magelang”. Semarang: Jurnal Ekonomi Pembangunan. Vol,1. N0.2.

Aditya, Ivan. 2017. Harga Bahan Pokok di Sragen Melonjak. https://krjogja.com/web/news/read/53063/Harga Bahan Pokok di Sragen Melonjak. Diakses pada 6 Juli 2019.

Ambardi, U.M dan Socia, P. 2002. Pengembangan Wilayah dan Otonomi Daerah. Pusat Pengkajian Kebijakan Pengembangan Wilayah (P2KTPW-BPPT), Jakarta.

Arif, Muhammad, dkk. 2019. "Distribusi Spasial Masyarakat Terkategori Miskin Dalam Basis Data Terpadu Kabupaten Sragen”. Universitas Muhammadiyah Surakarta.

Arif, Muhammad; Utomo, Yuni Prihadi. 2016. “Konsentrasi Spasial Industri Industri Unggulan Kota Surakarta”. Fakultas Ekonomi dan Bisnis: Universitas Muhammadiyah Surakarta. ISSN 2407-9189.

Arsyad, L. 1999. Pengantar Perencanaan dan Pembangunan Ekonomi Daerah. Edisi Pertama, BPFE, Yogyakarta.

Arsyad, S. 2000. Konservasi Tanah dan Air. UPT Produksi Media Informasi. Lembaga Sumberdaya Informasi. Institut Pertanian Bogor, IPB Press, Bogor

BPS Kabupaten Sragen (2016). Sragen dalam Angka 2017.

BPS Kabupaten Sragen (2017). Sragen dalam Angka 2018.

BPS Kecamatan Gemolong (2017). Gemolong dalam Angka 2018.

BPS Kecamatan Gesi (2017). Gesi dalam Angka 2018.

BPS Kecamatan Gondang (2017). Gondang dalam Angka 2018.

BPS Kecamatan Jenar (2017). Jenar dalam Angka 2018.

BPS Kecamatan Kalijambe (2017). Kalijambe dalam Angka 2018.

BPS Kecamatan Karangmalang (2017). Karangmalang dalam Angka 2018. 
BPS Kecamatan Kedawung (2017). Kedawung dalam Angka 2018.

BPS Kecamatan Masaran (2017). Masaran dalam Angka 2018.

BPS Kecamatan Miri (2017). Miri dalam Angka 2018.

BPS Kecamatan Mondokan (2017). Mondokan dalam Angka 2018.

BPS Kecamatan Ngrampal (2017). Ngrampal dalam Angka 2018.

BPS Kecamatan Plupuh (2017). Plupuh dalam Angka 2018.

BPS Kecamatan Sragen (2017). Sragen dalam Angka 2018.

BPS Kecamatan Sambirejo (2017). Sambirejo dalam Angka 2018.

BPS Kecamatan Sambungmacan (2017). Sambungmacan dalam Angka 2018.

BPS Kecamatan Sidoharjo (2017). Sidoharjo dalam Angka 2018.

BPS Kecamatan Sukodono (2017). Sukodono dalam Angka 2018.

BPS Kecamatan Sumberlawang (2017). Sumberlawang dalam Angka 2018.

BPS Kecamatan Tangen (2017). Tangen dalam Angka 2018.

BPS Kecamatan Tanon (2017). Tanon dalam Angka 2018.

BPS Provinsi Jawa Tengah (2016). Jawa Tengah dalam Angka 2017.

BPS Provinsi Jawa Tengah (2017). Jawa Tengah Dalam Angka 2018.

Bungin, Burhan. 2001. Metodologi Penelitian Kualitatif Aktualisasi Metodologis ke Arah Ragam Varian Kontemporer. Jakarta: Rajawali Pers.

Chengliang Liu and Ruilin Yu, "Spatial Accessibility of Road Network in Wuhan Metropolitan Area Based on Spatial Syntax". Journal of Geographic Information System, pp. 128-135, Apr. 2012.

Dede, Moh; dkk. 2016. "Analisis Potensi Perekonomian Sektor Pertanian, Kehutanan, dan Perikanan Serta Pertambangan dan Penggalian Di Pantura Jawa Barat”. Bandung: Jurnal Pendidikan Geografi. ISSN: 2580-1333. 
Emilia; Zulgani. 2015. "Identifikasi Sektor - Sektor Potensial di Kabupaten Batanghari”. Jambi: Jurnal Ekonomi Pembangunan. Vol.10, No.1.

Faturrahman, Mukhamad, Burhanuddin. 2017. "Pemetaan Potensi Wilayah Untuk Menunjang Kebijakan Pangan Kabupaten Pacitan”.'Vol.7, No.2.

Fujita, M., Krugman, P., And Venables, A.J. 1999. The Spatial Economy : Cities, Regions, And International Trade. Cambrige And London : The Mit Press

Himani. 2014. “An Analysis of Agriculture Sector in Indian Economy”. Journal Of Humanities And Social Science. Volume 19, Issues.1, Ver.X. Februari 2014.

Hussin and Wuan Ching. 2013. "The Contribution of Economic Sectors to Economic Growth: The Cases of Malaysia and China. International Journal of Academic Research in Economics and Management Sciences". Vol.2, No.2 Maret 2013.

Ibrahim, Ismail. 2018. "Analisis Potensi Sektor Ekonomi Dalam Upaya Peningkatan Pertumbuhan Ekonomi (Studi Empiris Pada Kabupaten dan Kota di Provinsi Gorontalo tahun 2012-2016)”. Gorontalo: Jurnal Studi Pembangunan. Vol.1, No.1.

Ivanov, Stanislav; Webster, Craig. 2010. "Decomposition Of Economic Growth In Bulgaria By Industry”. Journal Economic Studies. Vol. 37 Edisi 2 hlm. 219-227.

Kurniawan, Bambang. 2016. “Analisis Sektor Ekonomi Unggulan Kabupaten Kerinci Provinsi Jambi”. Jambi: Jurnal Ekonomi Islam. Vol.4, No.1.

Marsden, Terry; Sonnino, Roberta. 2008. "Rural development and the regional state: Denying multifunctional agriculture in the UK”. Journal of Rural Studies. Vol.1, No.6.

Mudrajad, Kuncoro. 2002. Manajemen Perbankan: Teori dan Aplikasi. Yogyakarta : BPFE.

Nugroho, Sidiq Permono; dkk. 2017. “Analisis Potensi Ekonomi dan Pengembangan Klaster Ikan di Kabupaten Sragen”. Surakarta: Fakultas Ekonomi dan Bisnis.

Prawira, Yudha; Hamidi, Wahyu. 2013. "Transformasi Struktur Ekonomi Kabupaten Siak Tahun 2001-2010”. Riau: Jurnal Ilmu Ekonomi Pembangunan. Vol.21, No.1. 
Peraturan Perundang-undangan No 45 Tahun 2009 mengenai perikanan.

Prawoto, Nano. 2010. "Pengembangan Potensi Unggulan Sektor Pertanian". Yogyakarta: Jurnal Ekonomi dan Studi Pembangunan. Vol.11, No.1.

Purnomo, Hanny P. 2007. Penebar Swadaya.

Qomariyah, Siti; dkk. 2018. "Analisis Potensi Wilayah Berbasis Komoditas Pertanian Tanaman Pangan Serta Kontribusinya Terhadap Perekonomian Kabupaten Bondowoso”. Jember: Jurnal Studi Agribisnis. Vol.11, No.1.

Rasyid, Abdurrahman. 2016. “Analisis Potensi Sektor Potensi Pertanian Di Kabupaten Kediri Tahun 2010-2014”. Kediri: Jurnal Ekonomi Pembangunan. Vol.14, No.2.

Robinson, Tarigan. 2012. Perencanaan pembangunan wilayah. Jakarta: Bumi Aksara.

Samuel Paul, 1967. "Summary on Factor-Price Equalization”. International Economic Review.

Sapriadi; Hasbiullah. 2015. "Analisis Penentuan Sektor Unggulan Perekonomian Kabupaten Bulukumba”. Makassar: Fakultas Ekonomi dan Bisnis. Vol.1, No.1.

Saragih, Bungaran. 2001. Suara dari Bogor : Membangun Sistem Agribisnis. Yayasan USESE bekerjasama dengan Sucofindo. Bogor.

Setiaji, Pratomo. 2012. "Sistem Informasi Geografis Industri di Kabupaten Kudus". Surakarta: Fakultas Teknik Muria Kudus. ISBN 979-26-0255- 0.

Sjafrizal. 2012. Pertumbuhan Ekonomi dan Ketimpangan Regional Wilayah Indonesia Bagian Barat. Jakarta: Jurnal Buletin Prisma.

Soebagyo, Daryono; Hascarya, Arifin S. 2015. "Analisis Sektor Unggulan Bagi Pertumbuhan Ekonomi Daerah di Jawa Tengah”. Surakarta: Jurnal Ekonomi Pembangunan. Vol.24.No.07.

Sugiyono. 2011. Metode Penelitian Kuantitatif dan Kualitatif dan $R$ \& $D$. Bandung: CV Alfabeta.

Sukirno, Sadono. 2004. Pengantar Teori Makroekonomi. Jakarta: PT Raja Grafindo Persada. 
Sumiharjo, Tumar. 2008. Daya Saing Berbasis Potensi Daerah. Puskomedia: Bandung.

Tarigan, Robinson. 2005. Ekonomi Regional: Teori dan Aplikasi. Bumi Aksara: Jakarta.

Tjiptoherijanto, Prijono. 1997. Migrasi, Urbanisasi dan Pasar Kerja di Indonesia. Jakarta: Penerbit Universitas Indonesia.

Undang-Undang No.18 Tahun 2004 mengenai perkebunan serta Buku Konsep dan Definisi Baku statistik pertanian (BPS).

Undang-Undang No.22 Tahun 1999 mengenai Pemerintah Daerah 